\title{
Aesthetic Energies Portrayed in Indonesian Novels in the 2000s
}

\author{
Sugiarti \\ University of Muhammadiyah Malang, Indonesia \\ atika umm@yahoo.co.id
}

\begin{abstract}
This study aims at revealing (1) aesthetic codes in Indonesian novels in the 2000s and (2) aesthetic forms in Indonesian novels in the 2000s. Those two problems are considered necessary to study further as aesthetic conception is formed by making uses of cohesive language codes. This current study employed descriptive method by in-depth meaning interpretation. The data had been taken from novels in the decade of $2000 \mathrm{~s}$, namely; Jatisaba by Ramayda Akmal, Geni Jora by Abidah EI Khalieqy, and Lanang by Yonathan Rahardjo. The data were in the forms of narrations, represented by dialogues and monologues of the characters containing verbal and non-verbal aesthetics. The collected data were, then, analyzed by means of; (1) descriptive approach, (2) hermeneutic approach, and (3) interactive-dialectical analysis based on the facts. The research findings were elaborated as follows; (1) aesthetic codes in Indonesian novels in 2000s are detected through the use of aesthetic expressions by making use of words or phrases representing social, cultural, and political nuances. The unity built in the story and narration has contributed to an insight that the language provides ample energies to build up the story plots; (2) aesthetic forms in Indonesian novels in 2000s have been marked by the changes of society over time and ,thus, aesthetic conception is embedded into the content of the stories.
\end{abstract}

Keywords: Aesthetic energy, Language codes, Language cohesion, Extrinsically

\section{INTRODUCTION}

Art, accompanied by its immense identities, constitutes a potential field for authors to play and express with creativity processes. Modern arts, for instance, reflectively are flexible in playing with the extant media so as to enable people to formulate spiritual experiences that are absurd. Those experiences are then, expressed into further deeper forms, in this case, true meanings and souls. Art enables us to demolish any stiffness of points of view to digest any particulars as well as to be brave in viewing new and unpredictable sides of ourselves. Art incessantly offers opportunities for the art enthusiasts to review anything perceived as valuable, in unique, personal, and honest ways. The term "unique" emerges as art defines its divine language, which is specific, trespassing any conceptual categories to link various meanings of anything. Aesthetic nuances built in any literary works historically are justified by the metamorphosis of artworks along with their meanings. Theoretically, this is inseparable from the emergence of literary works that sociologically is a reflection of society, which is of much influenced by historical conditions. In essence, literary works provide authors with dialectical test between the authors themselves and the attached social situations; it can also be the explanation of dialectical history insinuated into literary works [2], [8]. The touch between aesthetics and socialcultural environment has made literary works equipped with souls utilizing aesthetic codes as the media to deliver messages to target readers.

In literature, the communication system between literary works and aesthetic codes is the point of interest for discussion [9], [11]. Aesthetic codes are strongly tied to the use of language as the media of expression and communication used by the authors to express and explore their ideas. In this regard, they will encounter aesthetic and stylistic spaces. Aesthetic spaces in modern novels convey more uniqueness compared to their formers. This has been shown by a great amount of markings used to enrich aesthetic energies.

The entire experiences and cultures of man-beings base on markers and possess symbolic dimensions that are inseparable from their main problems of markers as well as the play of markers that potentially will not deem to end and it is not a tightly connected concept to particular markers and language as the imaginative function [2], [5], [11]. Principally, language markers deal with the optimization of language energies manifested in aesthetic energies that draw power to build certain nuances. Those nuances offer changes over life dimensions of literary works. Henceforth, there are two sides to comprehend; (1) language as an imaginative function and (2) language functioning as extrinsic components building up literary works.

Language is said to be a framework of thought and based on linguistic determinism theory; man-beings find it hard to think out of the framework. Provided that the language system is formed, it will influence the way society discuss and interpret their world. This is in line with the cultural concepts, covering semiotics, markers, and symbols produced and utilized by man-beings [4], [10], [15]. Those symbols will eventually bring about thoughts presented by authors. The thoughts are based on creative and imaginative processes. Those symbols reveal deep meanings to be interpreted by readers. 
Departing from the above elaboration, this study proposes two problems: (1) How are aesthetic codes applied in Indonesian novels in the 2000s? and (2) How are aesthetic forms expressed in Indonesian novels in the 2000s?

\section{METHOD}

This research employed descriptive design by means of in-depth interpretation of meanings. The data were taken from novels in the decade of the 2000s, namely; Jatisaba by Ramayda Akmal, Geni Jora by Abidah El Khalieqy, and Lanang by Yonathan Rahardjo. The data were in the forms of narrations, represented by dialogues and monologues of the novels' characters consisting verbal and non-verbal aesthetics. The collected data were analyzed using: (1) descriptive approach, (2) hermeneutic approach, and (3) interactive-dialectical analysis based on the facts.

\section{RESULTS}

\section{Aesthetic Codes in Indonesian Novels in 2000s}

Aesthetic is not solely connected to language, but to the entire aspects of literary works as well. It discusses the concept of beauty ontologically as the representation of God' mighty wealth, immanent aspect of beauty projected through beautiful wordings, as well as psychologically affecting target readers [3]. Aesthetic codes are interconnected to the intensive use of language in projecting the holistic realities of life aiming at attracting readers.

Angin menusuk-nusuk (the piercing wind). Bibirku bergetar (the trembling lips), sama sekali tak bisa kukendalikan. Ingatan tentang tuan Kim dan rumah ditambah angin yang diam tapi ganas (silent yet vicious wind)...[1:21].

The phrase angin yang menusuk-nusuk (the piercing wind) reminds us of the bitter past. It is amplified by the phrase bibir bergetar and angin yang diam tapi ganas (the trembling lips and silent yet vicious wind) that expresses someone who is powerless in facing life facts. In aesthetics, visible entities are not passive but constructive [12]. Hereinafter, the construction of those entities aesthetically expressed brings in specific meanings.

Language possesses its power to express magical entities. The proper choice of words as eagle and the floating and approaching fish elaborates something enabling the movement of thought in interpreting particular matters. This has portrayed that the sharp eye look pull the surrounding entities to follow the movement. The meanings of words and phrases have their own beauty to relish, as in the following excerpt.

Aku berharap seseorang di antara pemuda-pemuda itu, seseorang yang matanya seperti elang (eagle). Tatapan matanya bisa membuat ikan-ikan mengambang dan mendekat (the floating and approaching fish) [1:77]
A man with his will can win everything he wishes. However, if he cannot fulfil his will, the aesthetic symbol will be wajah yang kusut, menunduk lesu bak dian hampir padam (a disheveled face, drooping down like a drooping down light). It reflects the drooping desire. Masculinity and desire are gone. It is quoted from the following.

Namun larungan tak diterima karena syarat tak terpenuhi... Aku tergila gila menatap wajah kusut (a disheveled face) yang biasanya penuh gaya dan binar cahaya itu. Menunduk lesu bak dian hampir padam (drooping down like a drooping down light) [6: 21].

In general, the education level has made women knowledgable and insighful. Educated women are adorned by intelligence and skills. Women are symbolized by gudang mutiara, perbendaharaan kerajaan, emas dan permata dunia (a pearl source, royal treasury, gold and world gems). Those phrases portray how skillful woman are with their abundant knowledge and wealth. However, in fact, some women are still treated unfairly in real world. This sort of concept is shown in the following excerpt.

Nadia Masid, berasumsi, boleh jadi kaumnya adalah gudang mutiara, perbendaharaan kerajaan, emas dan permata dunia (a pearl source, royal treasury, gold and world gems), karena hanya objek-objek seperti itu menarik untuk dicemburui, diserang, dan dirampok nafsu-nafsu primitive [6:30].

An author might describe the combination of the souls between a mother and a daughter. A mother devotes her life-long love and affection as well as sacrifice. Her daughter's happiness is what a mother always aims at. The understanding of the author about a mother as a character affects the messages embedded into story narration. A mother is a source of power in life, pride, savior for her children and family. The following except talks about Dewi, a mother.

'Ibu dan anak yang begitu saling menyayangi ... Semua tercermin manakala aku terlibat jamuan makan malam bersama mereka di meja makan yang bernyawa sebagai meja keluarga (a lively dining table as a table of family).' Tak berapa lama berlalu, Dewi tidur dalam pelukan selimut hangat bersama Bu Surya, Ibunya [11: 267-268].

Authorities in dictatorship reign do not care about their citizens. They rule on their on basis as they wish, taking no side on their citizens. Poor citizens are restricted in strict law. They are far from prosperity in their own country.

\section{Aesthetic Forms in Indonesian Novels in the 2000s}

Aesthetic forms in Indonesian novel in the 2000s are expressed in various ways, consisting of cultural, social, philosophical, and religious aspects. Aesthetic forms are generally well combined so as to create dense cohesiveness. In this context, language plays its major and essential role in portraying aesthetics to be used by 
authors to link extrinsic components of literary works as artworks.

\begin{abstract}
Suara gemericik gelang kaki (the rattling anklets) menyeruak di tengah-tengah penonton. Muka mereka merah jambu kehitaman kebanyakan blush on (their black pink faces full of blush on). Tangan mereka lentur memainkan kudanya ke kiri dan kanan (their hands flexed to play the horse to the left and right). Kemenyan mulai mengepul di beberapa sudut arena bersama sesajen (billowing frankincense and offerings in several corners of the arena) yang mulai diincar-incar penonton untuk diperebutkan ketika pertunjukan usai. Pisang raja dan pisang emas (golden and king bananas) menjadi favorit ibu-ibu. Sementara anak-anak rela berdesakan memperebutkan jajan pasar (munching cakes) sisa sesajen. Bunga-bungaan atau kelapa muda (flowers and young coconuts) ... [1:94-95].
\end{abstract}

Aesthetics portrayed in the above excerpt are exploring local wisdoms. It is displayed in one of art games called ebeg. Ebeg is a performing art rich of functions and values of the locals. This performance is inseparable from mystical aspects. Most of the attractions are beyond human capability and sensibility. The players of ebeg put on heavy make-up, shown by over-applied blush-on in dark red color. To enliven the show, all players wear anklets as accessories. This is in line with the notion of Plato that beauty is physically simple, and it is shifted to the view that the most beautiful one is "the unified one"; "unity" marks beauty, and many others [13]. Accordingly, the unification of all components is the manifestation of the perfection of the show. It all meets the taste of the locals. Taste has broad conception. It covers up traditions, perspectives, philosophies, ethic and aesthetic values, as well as local cultures [7].

The author is not only experiencing those mystical rituals, but also noticing and sensing that the surrounding society and environment are observing those mystical rituals. Those rituals have substantially colored the novel Lanang, as seen in the following excerpt.

Makhluk itu tanpa ancang-ancang melompat,

melayang, terbang. Hilang dalam kekelaman malam

(disappear in the dark night). Bulan dilangit tak

kuasa menerangi jejaknya. Angin masih berembus dingin ... [11]

The ghosts haunting at night have made the character Lanang enquiring. He feels something strange about them. There have not been those sorts of animal extant in real life. He experiences confusion of either being extant or absent.

Aesthetically, the author through the character Elya describes an ideal, beautiful, intelligent, and appealing lady. Her inner beauty is reflected through her high level of education. This sort of image has been brought up to readers directly and indirectly. This supports Endraswara [3] saying that aesthetic relates to the psychological aspect of readers so as that they reflect from the reality portrayed in the literary work. The following excerpt is the description of Elya.

Aku ingin menghindar... Elya memiliki sebuah kekuatan (power), mungkin karisma (charisma), pesona yang memancar dari aura batinnya (appealing charm and aura). Tak dapat kumungkiri, kecermelangan Elya lebih tinggi, membias dari kecerdasan otak dan kejelitaan (her intelligence and beauty) [6: 69]

As for linguistic aspect, responsible novels are novels written on neat and logical language. Therefore, novels should display coherence (logical sentences) and cohesiveness (neat language) in order to be appealing.

Women in royal palace bear the same destiny. They experience cultural treatments, constructions, comprehensions, and social incidences; all of which are public [4]. After getting married, they will be abandoned and replaced by another one, as what has been experienced by Ibu Glonggong. The noble man with well-trimmed look and scent is keen on young and finelooking girls. The following excerpt supports the information.

Setelah peristiwa memalukan di dalam ndalem Suwandan, aku jadi cukup dekat dengan priyayi keraton yang selalu tampil klimis dan wangi itu (the noble man with well-trimmed look and scent). Dengan Kenalannya Surya telah memberitahuku sesuatu yang sebelumnya tak pernah kusadari: betapa menderitanya ibu (how suffering my mother is) [11:62].

The power of those symbols derives from the authors' abilities to identify facts in a very fundamental stage. They are to reveal divine entities, things that are normative and comprehensive [4], [14]. Those symbols also display human desire insatiable. Royal palace is a magical symbol to inherit colonialism over a lowerclass society. Literature explores and actualizes various number of life aspects, including the marginalized women.

\section{CONCLUSION}

Aesthetic codes in Indonesian novels in the 2000s are detectable through the use of aesthetic language by means of words, phrases, and sentences portraying human lives. The unity of the narrations offers the notion that language contributes powerfull energies to construct appealing nuances.

Aesthetic forms in the Indonesian novels in the 2000s tend to mark changes over certain periods of time so as that aesthetic conception emerges and connects to social, cultural, technological, historical, and religious aspects in the stories, arriving at the lively portrayal of real life.

\section{REFERENCES}

[1] Akmal, Raymada. Jatisaba. Jakarta: Pressindo. 2004.

[2] Eagleton, Terry. Teori Sastra Sebuah Pengantar Komprehensif.Yogyakarta: Jalasutra. 2006. 
[3] Endraswara, Suwardi. Metode Penelitian Sastra. Yogyakarta: CAPS. 2013.

[4] Geertz, Clifford. Tafsir Kebudayaan (Terjemahan Budi Susanto). Yogyakarta: Kanisius. 1992.

[5] Halliday, Michael Alexander Kirkwood. Language and Education. New Yorks: Continuum. 2007.

[6] Khalieqy. El Abidah. Geni Jora. Bandung: Mizan Media Utama. 2009.

[7] Koentjaraningrat. Sejarah Teori Antropologi II. Jakarta: UI Press. 1990.

[8] Langland, Elisabeth. Society in the Novel. United States of America: The University of North Carolina Press. 1984.

[9] Setiyono, Junaedi. Glonggong. Jakarta: Serambi Ilmu Semesta. 2007.
[10] Sugiarti, Verbal Expressions of Saman Novel by Ayu Utami. Paper Presentation in $4^{\text {th }}$ International Conference the Community Development in ASEAN . 2017.

[11] Rahardjo, Yonathan. Lanang. Jakarta: Pustaka Alvabet. 2008.

[12] Ratna, Nyoman Kutha. Estetika Sastra dan Budaya. Yogyakarta: Pustaka Pelajar. 2007.

[13] Sutrisno, Muji; Christ Verhaak. Estetika Filsafat Keindahan.Yogyakarta: Kanisius. 1993.

[14] Suwondo, Tirto. Pragmatisme Pascakolonial. Trilogi Gadis Tangsi dalam Sistem Komunikasi Sastra. Pustaka Pelajar. 2016.

[15] Thomas, Linda; Shan Wareing. Bahasa, Masyarakat dan Kekuasaan. Yogyakarta: Pustaka Pelajar. 2006. 